\title{
Identification of Alkaloid's Profile in Ficus benjamina L. Extracts with Higher Antioxidant Power
}

\author{
Silvia Novelli, Canuti Lorena, Canini Antonella \\ Department of Biology, University of Rome "Tor Vergata", Rome, Italy \\ Email: canini@uniroma2.it
}

Received 20 November 2014; revised 6 December 2014; accepted 21 December 2014

Copyright (C) 2014 by authors and Scientific Research Publishing Inc.

This work is licensed under the Creative Commons Attribution International License (CC BY).

http://creativecommons.org/licenses/by/4.0/

(c) (i) Open Access

\begin{abstract}
Different classes of known alkaloid compounds were identified for the first time in leaves and barks of Ficus benjamina $L$. from Moraceae family. The identification of 28 alkaloids in $F$. benjamina leaves and 14 alkaloids in its barks was identified using chromatographic analysis as Gas Chromatography associated to Mass Spectrometry (GC-MS). This characterization analysis allows to verifying the presence of different alkaloids type-classes in both leaves and barks, such as isoquinoline class, indole class and quinolizidine class. The quantification results are deduced by analysis with spectrophotometric assay, using a calibration curve of boldine as standard alkaloid that reveals the presence of $26 \pm 0.1 \mu \mathrm{g}$ of alkaloids boldine equivalent in 1 gram of $F$. benjamina leaves and $3.8 \pm 0.1 \mu \mathrm{g}$ alkaloids boldine equivalent in 1 gram of its barks. A significant correlation was observed between the total alkaloid content of crude extracts and 2,2-diphenyl-1-picrylhydrazyl assay (DPPH), suggesting that the level of antioxidant activity in this species is strongly correlated to the alkaloid content. These findings should provide useful information for future on the pharmaceutical properties of these alkaloids from F. benjamina.
\end{abstract}

\section{Keywords}

Ficus benjamina, Alkaloids, Columbamine, Antioxidant Power

\section{Introduction}

Medicinal plants are known to be an important source of new chemical substances with potential therapeutics effects [1]-[4]. Alkaloids are some of these substances that have different structures and many show a range of pharmacological activities. They are classified according to the amino acids that provide their nitrogen atom and 
part of their skeleton and normally readily separable from the other metabolites as a result of their basicity [2]. The literatures report that a variety of analysis techniques such as high performance liquid-chromatography (HPLC) [3]-[7] [9]-[12] Gas Chromatography-Mass Spectrometry/Flame Ionization (GC-MS/FID) [5] [8] [9], thin layer chromatography (TLC) [5], have been used for separation and/or determination of the volatile components of plants such as alkaloids. GC-MS is one of the most important instrumental separation techniques for analysing complex mixtures, identifying the separated components by using mass spectra [13].

The genus Ficus is a member of the Moraceae family growing in tropical and subtropical regions and consists of over 800 species [14]. Previous studies on Ficus spp. reveal the presence of several compounds such as alkaloids [15], triterpenes [16], ascorbic acid [17] and flavonoids [18]. Notable species of Ficus is F. benjamina L., a medium size tree with several spreading branches from the base commonly known as weeping fig, native of tropics South Africa, Australia, tropical central Africa and West Africa [19]. Well known due to its medicinal potential, indigenous communities employ this plant to treat skin disorder, inflammation, malaria, vomiting and it's also used as antimicrobial, antipyretic and antinociceptive [20]-[23]. The leaves, barks and fruits contain various bioactive constituents like cinnamic acids, lactose, naringenin, quercetin, caffeic acid and stigmasterol [22]. The alkaloids presence in this plant was verified in a preliminary study on aqueous and ethanolic extracts of its "variegate" fruits for antimicrobial effects on Staphylococcus aureus, Escherichia coli, Salmonella typhi, Klebesiella pneumonia and Pseudomonas aeruginosa [24]. In the present paper we report the chemical investigation of alkaloids in $F$. benjamina evaluating the total alkaloid content with a spectrophotometric assay, following a chromatographic analysis for the characterization of various class-derivative alkaloids interesting for putative pharmaceutical inquiry. The antioxidant capacity of $F$. benjamina extracts was also tested with 2,2-diphenyl-1-picrylhydrazyl assay (DPPH).

\section{Materials and Methods}

\subsection{Materials}

F. benjamina stems and leaves were collected from the Botanical Garden of University of Tor Vergata in Rome, Italy in January 2014. Total alkaloids content and antioxidant capacity were measured with a spectrophotometer Cary 50 Bio UV-visible (Varian, Italy) associated to a software Cary win UV (Varian, Italy). Characterization of alkaloids was performed using GC-MS Shimadzu QP2010 GC system (Shimadzu, Italy) equipped with a high resolution mass spectrometer QP2010 Plus using EI revelation mode.

\subsection{Methods}

Methanol, n-hexane, chloroform, formic acid, were Carlo Erba HPLC solvents (Milan, Italy). Boldine, bromocresol green (BCG) and 1-diphenyl-2-picryl hydrazyl radical (DPPH) standard were purchased from SigmaAldrich (Italy). Millipore Express ${ }^{\mathrm{TM}}$ PLUS $0.22 \mu \mathrm{m}$ filter was used for filtration (Sigma-Aldrich, Italy). For the alkaloids extraction the leaves were cut in small pieces, pulverized with liquid nitrogen, defatted with n-hexane for $24 \mathrm{~h}$ and extracted for one hour with a solution of $3 \%$ formic acid in $70 \%$ methanol $/ \mathrm{dH}_{2} \mathrm{O}(\mathrm{v} / \mathrm{v})$. Then the solution was filtrated with $0.22 \mu \mathrm{m}$ filter and it was subjected to acid-base treatment, by the addition of concentred ammonia until the solution reached basic $\mathrm{pH}$. The filtrate was extracted with an equal volume of chloroform, then washed for eliminate ammonia residues. Water residues in chloroform are removed with sodium sulphate. Finally, the chloroform solvent from the acid-base treatment was evaporated through nitrogen flow and the crude extract is resuspended in chloroform. Chloroform aliquots of extract were analysed with GC-MS.

\subsection{GC-MS Analysis}

GC-MS characterization was carried out using a specific software: GC-MS solution version 2.53 SU3, associated to analytical instrument for data acquisition and processing. An RTX-5MS (30 m $\times 0.25 \mathrm{~mm}$ id, film thickness $0.25 \mu \mathrm{m}$ ) fused-silica capillary column was employed. Operating conditions were as follows: splitless mode, initial oven temperature, $70^{\circ} \mathrm{C}$ for $2 \mathrm{~min}$, then to $200^{\circ} \mathrm{C}$ at $25^{\circ} \mathrm{C} \cdot \mathrm{min}^{-1}$ and held for $5 \mathrm{~min}$, and then the final temperature of $300^{\circ} \mathrm{C}$ for $10 \mathrm{~min}$ at $3^{\circ} \mathrm{C} \cdot \mathrm{min}^{-1}$, injector and detector temperatures, $250^{\circ} \mathrm{C}$ and $300^{\circ} \mathrm{C}$; carrier gas, Helium, $1.0 \mathrm{~mL} \cdot \mathrm{min}^{-1}$; injection volume, $2 \mu \mathrm{L}$. Mass spectrometer conditions are: the voltage ionization $70 \mathrm{eV}$, ion source temperature $230^{\circ} \mathrm{C}$ and MS transfer line it $250^{\circ} \mathrm{C}$. 
Qualitative data were obtained with comparison of spectra registered in a NIST library (NIST08) included in the software GC-MS solution.

$F$. benjamina extracts composition is expressed as \% area of each compound identified with NIST library in the sample chromatogram respect to the total alkaloids peak areas in the same chromatogram [25].

\subsection{Spectrophotometric Assay}

Total alkaloid content evaluation was carried out with a spectrophotometric method based on the reaction with BCG [26], with appropriate changes on $F$. benjamina extracts. Briefly, BCG solution was prepared by heating $69.8 \mathrm{mg} \mathrm{BCG}$ (Sigma-Aldrich, Italy) with $3 \mathrm{ml}$ of $2 \mathrm{~N} \mathrm{NaOH}$ and $5 \mathrm{ml}$ distilled water until completely dissolved and the solution was diluted to $1000 \mathrm{ml}$ with distilled water. Boldine (Sigma-Aldrich, Italy) standard solution was made in $\mathrm{HCl}$ solution $(\mathrm{pH} 2.5)$ at concentration of $1 \mathrm{mg} \cdot \mathrm{ml}^{-1}$. For the preparation of standard curve, accurately measured aliquots of boldine standard solutions were transferred each to different separatory funnels. Then, $5 \mathrm{ml}$ of $\mathrm{pH} 4.7$ phosphate buffer was added before $5 \mathrm{ml}$ of BCG solution and shacked vigorously. Furthermore, $5 \mathrm{ml}$ of chloroform was added and after shaking, a yellow-colored complex with a maximum absorption containing boldine-BCG solution was produced. The yellow complex in chloroform was finally recovered and the absorbance at $470 \mathrm{~nm}$ was measured against blank.

\subsection{Antioxidant Capacity Assay}

The DPPH scavenging ability in the $F$. benjamina barks and leaves extracts was evaluated by spectrophotometric method [25]-[27] with some modifications. Briefly, in this method, six ethanol dilutions of crude leaves and barks extracts (from 50 to $500 \mu \mathrm{g} \cdot \mathrm{ml}^{-1}$ ) was added to a $1.9 \mathrm{ml}$ of a ethanolic solution of DPPH $(65 \mu \mathrm{M}$ ) and acetate buffer $0.2 \mathrm{M} \mathrm{pH}$ 5.6. After $10 \mathrm{~min}$ at room temperature and in darkness, the absorbance was measured at $517 \mathrm{~nm}$ against a blank solution. DPPH solution and ethanol was used as control. The DPPH scavenging ability as percentage was calculated as: DPPH scavenging ability $=\left(A_{\text {control }}-A_{\text {sample }} / A_{\text {control }}\right) \times 100$. Then, a curve of $\%$ DPPH decrease absorbance versus concentration was plotted and a linear regression curve was established for $\mathrm{IC}_{50}$ calculation. $\mathrm{IC}_{50}$ show the concentration of initial sample required to scavenge $50 \%$ of DPPH free radicals. The experiment was repeated three times. $\mathrm{IC}_{50}$ values show the quantity of the sample, which is required to scavenge $50 \%$ of DPPH free radicals [27].

\subsection{Data Analysis}

All the determinations were performed in triplicates and data are expressed as the mean \pm standard deviation (SD).

\section{Results and Discussion}

\section{Chemical Composition and Antioxidant Capacity}

The crude extract yield obtained from $F$. benjamina extraction $\left(250 \pm 11 \mu \mathrm{g} \cdot \mathrm{g}^{-1}\right.$ leaves and $\left.190 \pm 9 \mu \mathrm{g} \cdot \mathrm{g}^{-1} \mathrm{barks}\right)$ requires a specific determination of alkaloids content since the extract contain other chemical compounds different from alkaloids class. Spectrophotometric determination of total alkaloids with BCG is a simple and sensitive method and does not need very specially equipment [26]. Is very important that the BCG can react with certain classes of alkaloids that have nitrogen inside their structure, but not including amine or amid alkaloids that not reacted with this reagent [26]. Results of BCG assay showed that the major content of alkaloids boldine equivalents is present in leaves extract $\left(26.0 \pm 0.1 \mu \mathrm{g}\right.$ boldine equivalents $\left.\mathrm{g}^{-1}\right)$ respect to barks extract $(3.8 \pm 0.1$ $\mu \mathrm{g}$ boldine equivalents $\mathrm{g}^{-1}$ ) from $F$. benjamina. Previous data [28] showed that alkaloids content in alkaloid producer species from Apocynaceae family have total alkaloid content major of $1 \mathrm{mg}$ boldine equivalent $\mathrm{g}^{-1}$ (for example Kopsia fruticosa leaves that contain $10^{5} \mu \mathrm{g}$ boldine equivalent $\mathrm{g}^{-1}$; Nerium oleander leaves that contain $1400 \mu \mathrm{g}$ boldine equivalent $\mathrm{g}^{-1}$ ), demonstrating that $F$. benjamina is not a greater source of alkaloids compounds. Spectrophotometric analysis, also demonstrate that alkaloids content in leaves are higher than barks alkaloids content, consistently with GC-MS data, that showed an higher number of alkaloids in leaves respect to barks and higher total relative areas (Figure 1).

However, although the content of alkaloids in this species appears to be low, data of the antioxidant capacity 


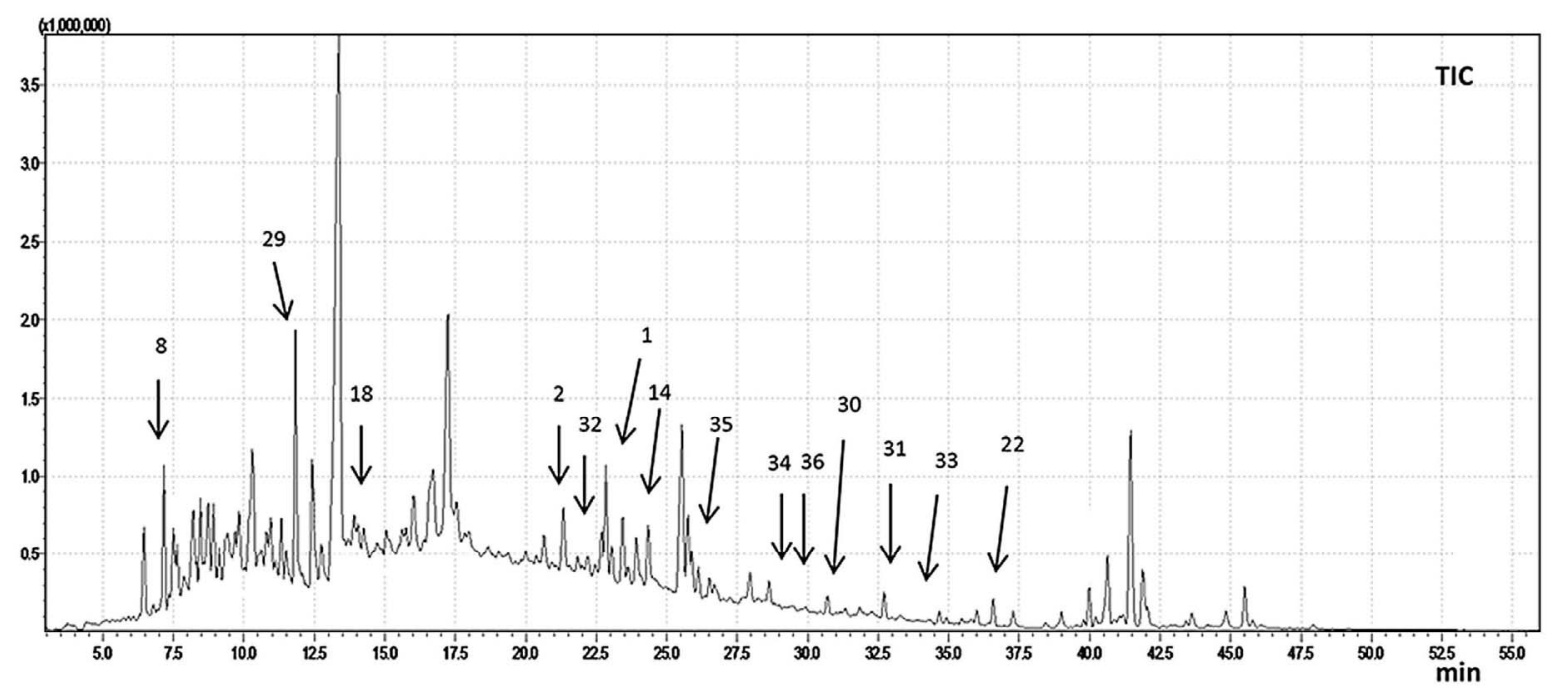

(a)

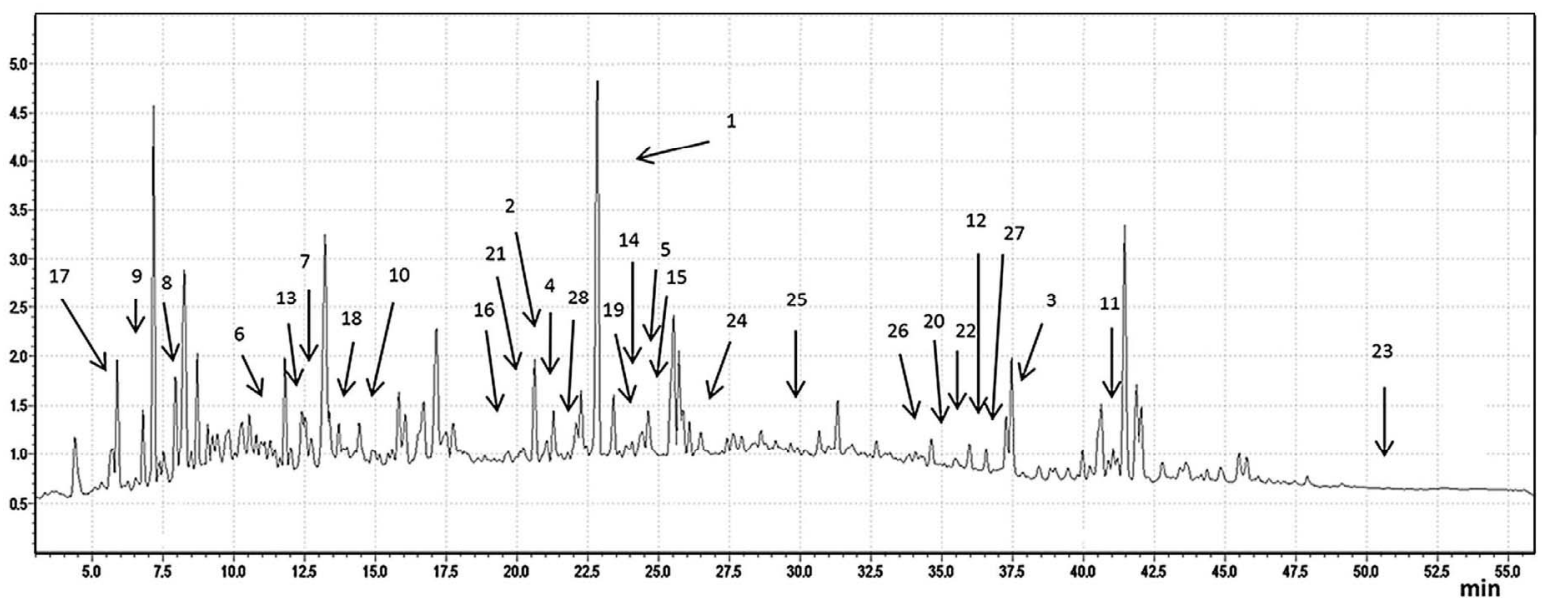

(b)

Figure 1. GC-MS chromatograms (total ion current) of the alkaloids fractions obtained from barks (a) and leaves (b) of $F$. benjamina. Alkaloids identified for each peak are reported in the Table 1.

show that the two extracts have high antioxidant power. Particularly, consistent with the spectrophotometric evaluation of total alkaloids, extracts from the leaves of $F$. benjamina show that $104.3 \pm 5.2 \mathrm{mg} \cdot \mathrm{ml}^{-1}$ of leaves are sufficient to produce $50 \%$ inhibition of DPPH radical compared to $469 \pm 23.4 \mathrm{mg} \cdot \mathrm{ml}^{-1}$ of $F$. benjamina barks, demonstrating a positive correlation with total alkaloids content and suggesting that the level of antioxidant activity in this species is strongly correlated to the alkaloids content. DPPH assay is a simple and sensitive method that uses a stable free radical to measure the antioxidant capacity of natural compounds. A significant correlation was observed between the total alkaloid content of crude extracts and DPPH assay results. DPPH assay results show that $F$. benjamina crude extracts presents a high antioxidant capacity, when compared with literature. In fact, a previous paper [29] reported that crude extracts of Tabernaemontana catharinensis fruits and branches, evaluated by the DPPH method and the content of alkaloids, respectively show an $\mathrm{IC}_{50}$ of 1155.91 $\mathrm{mg} \cdot \mathrm{ml}^{-1}$ of fruits crude extract and $202.17 \mathrm{mg} \cdot \mathrm{ml}^{-1}$ of branches crude extract. However, T. catharinensis contained more alkaloids equivalent with respect to $F$. benjamina.

The characterization of alkaloids in $F$. benjaminawas achieved using GC-MS analysis that permits to identify 28 alkaloids in leaves and 14 alkaloids in barks. The identification was performed according to evaluation of similarity percentage above the $80 \%$. In Table 1 , identified alkaloids were reported with their class of member ship (first column), the retention time $\left(\mathrm{T}_{\mathrm{r}}\right)$ in chromatograms (second column) and their percentage's areas (third 
Table 1. Alkaloids identified with GC-MS analysis in leaves and barks extracts. The data are given as the mean $\pm \operatorname{SD}(n=3)$.

\begin{tabular}{|c|c|c|c|c|}
\hline Family & Compound & $\mathrm{T}_{\mathrm{r}}(\mathrm{min})$ & $\%$ areas (leaves) & $\%$ areas (barks) \\
\hline Indole-type & $\begin{array}{c}6 \\
7 \\
15 \\
26 \\
32 \\
35 \\
36\end{array}$ & $\begin{array}{l}10.81 \\
12.07 \\
24.42 \\
34.01 \\
22.45 \\
25.15 \\
28.80\end{array}$ & $\begin{array}{c}5.85 \\
3.04 \\
1.12 \\
0.15 \\
- \\
- \\
-\end{array}$ & $\begin{array}{c}- \\
- \\
- \\
- \\
1.10 \\
0.21 \\
0.42\end{array}$ \\
\hline Indolyzidine-type & $\begin{array}{l}14 \\
30\end{array}$ & $\begin{array}{l}24.00 \\
30.40\end{array}$ & $\begin{array}{c}1.19 \\
-\end{array}$ & $\begin{array}{l}2.81 \\
4.22\end{array}$ \\
\hline Isoquinoline-type & $\begin{array}{c}1 \\
2 \\
3 \\
4 \\
5 \\
20 \\
25\end{array}$ & $\begin{array}{l}22.80 \\
20.60 \\
37.46 \\
22.37 \\
24.25 \\
35.45 \\
29.17\end{array}$ & $\begin{array}{c}31.07 \\
17.17 \\
9.63 \\
8.61 \\
6.42 \\
0.41 \\
0.03\end{array}$ & $\begin{array}{c}17.13 \\
14.79 \\
- \\
- \\
- \\
- \\
-\end{array}$ \\
\hline Quinolizidine-type & $\begin{array}{l}11 \\
18 \\
19 \\
24\end{array}$ & $\begin{array}{l}41.19 \\
13.70 \\
22.83 \\
26.70\end{array}$ & $\begin{array}{l}1.81 \\
0.94 \\
0.65 \\
0.22\end{array}$ & $\begin{array}{c}- \\
2.24 \\
- \\
-\end{array}$ \\
\hline Pyridine-type & $\begin{array}{c}8 \\
22 \\
23 \\
33\end{array}$ & $\begin{array}{c}7.50 \\
35.70 \\
51.02 \\
33.88\end{array}$ & $\begin{array}{c}2.23 \\
0.41 \\
0.36 \\
-\end{array}$ & $\begin{array}{c}2.85 \\
1.42 \\
- \\
0.73\end{array}$ \\
\hline Carbazol-type & $\begin{array}{l}12 \\
13 \\
16 \\
21\end{array}$ & $\begin{array}{l}35.95 \\
12.00 \\
19.51 \\
20.40\end{array}$ & $\begin{array}{l}1.38 \\
1.65 \\
1.04 \\
0.44\end{array}$ & $\begin{array}{l}- \\
- \\
-\end{array}$ \\
\hline Pyrrolizidine-type & $\begin{array}{l}17 \\
27\end{array}$ & $\begin{array}{c}6.70 \\
36.00\end{array}$ & $\begin{array}{l}0.76 \\
0.06\end{array}$ & - \\
\hline Steroidal-type & $\begin{array}{c}9 \\
31\end{array}$ & $\begin{array}{c}6.20 \\
33.30\end{array}$ & $\begin{array}{c}1.28 \\
-\end{array}$ & $\begin{array}{c}- \\
1.36\end{array}$ \\
\hline Quinoline-type & 34 & 28.23 & - & 0.57 \\
\hline Pyrrolidine-type & 28 & 22.60 & 0.09 & - \\
\hline Tropane-type & 29 & 10.90 & - & 28.09 \\
\hline Acridine-type & 10 & 14.41 & 1.84 & - \\
\hline
\end{tabular}

column). As showed in this table, identified alkaloids in $F$. benjamina are subdivided into 12 classes: the most numerous class is the isoquinoline (12 alkaloids between leaves and barks), indole ( 7 alkaloids between leaves and barks) and pyridine ( 6 alkaloids between leaves and barks); a moderate number of alkaloids are present into the carbazol class (4 molecules only in leaves), quinolizidine class (5 molecules between leaves and barks), indolizidine class ( 3 molecules between leaves and barks); a less number of alkaloids is present in pyrrolizidineclass ( 2 molecules only in leaves), quinoline class, pyrrolidine class, tropane class, acridine class that contains one alkaloid for each group. The different alkaloids here identified are showed in Table 1.

Areas of single alkaloids are expressed as percentage of the areas of each alkaloids respect to total alkaloids areas in the same chormatogram. Chemical structures of alkaloids identified are reported in Figures 2(a)-(c). In leaves more abundant alkaloids are columbamine (1) (31.07\%) and laudanosoline (2) (17.7\%); alkaloids with relative abundance from $5 \%$ to $10 \%$ are methylcoridaldine (3) (9.63\%), salsoline (4) $(8.61 \%)$, reticuline (5) (6.42\%), calycanthidine (6) $(5.85 \%)$ and alkaloids under $5 \%$ relative abundance that we found are akuammidine (7) (3.04\%), anabasine (8) (2.23\%), tomatidine (9) (1.28\%), acridine derivative (10) $(1.84 \%)$, sophocarpine (11) (1.81\%), neblinine (12) (1.38\%), harmine (13) (1.65\%), obscurinervinediol (14) $(1.19 \%)$, ergoline (15) $(1.12 \%)$, ellipticine (16) (1.04\%), indicine $\mathrm{N}$-oxide (17) (1.76\%), matridine (18) $(0.94 \%)$, scoulerine (19) $(0.65 \%)$, hydroxy morphine (20) $(0.41 \%)$, aspidospermidin (21) $(0.44 \%)$, nicodicodine (22) $(0.41 \%)$, adenocarpine (23) 


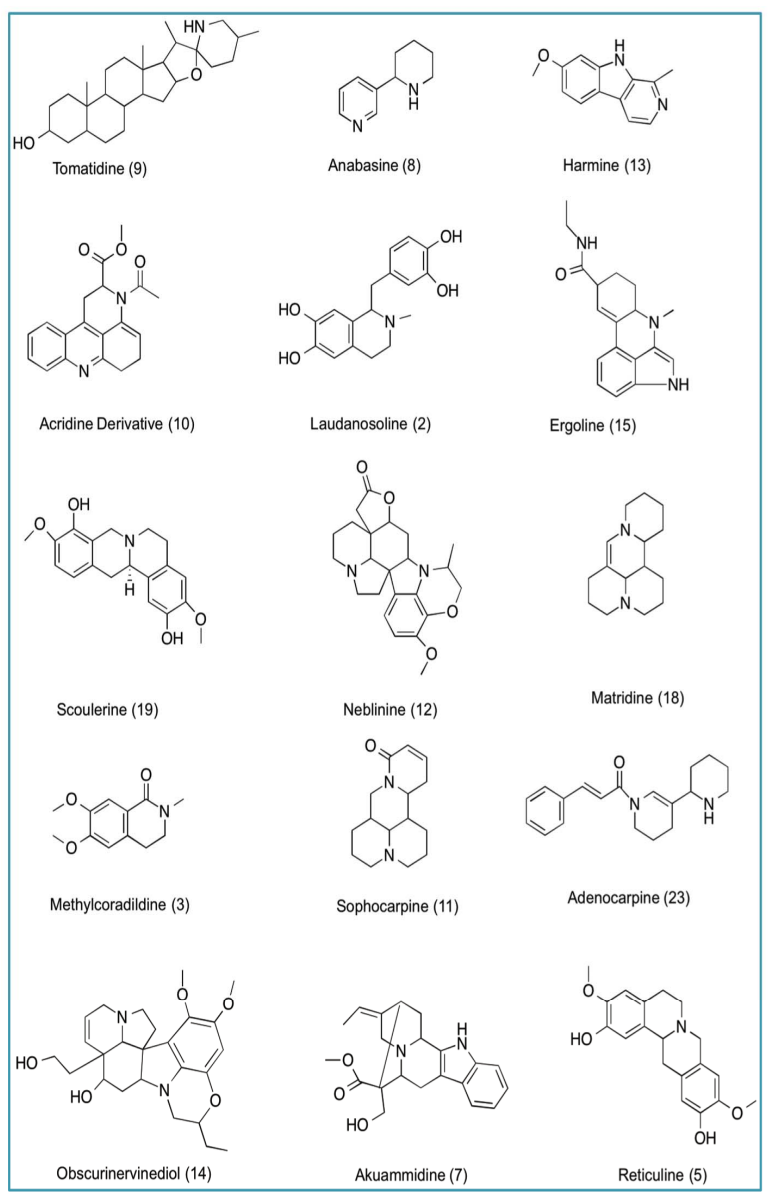

(a)

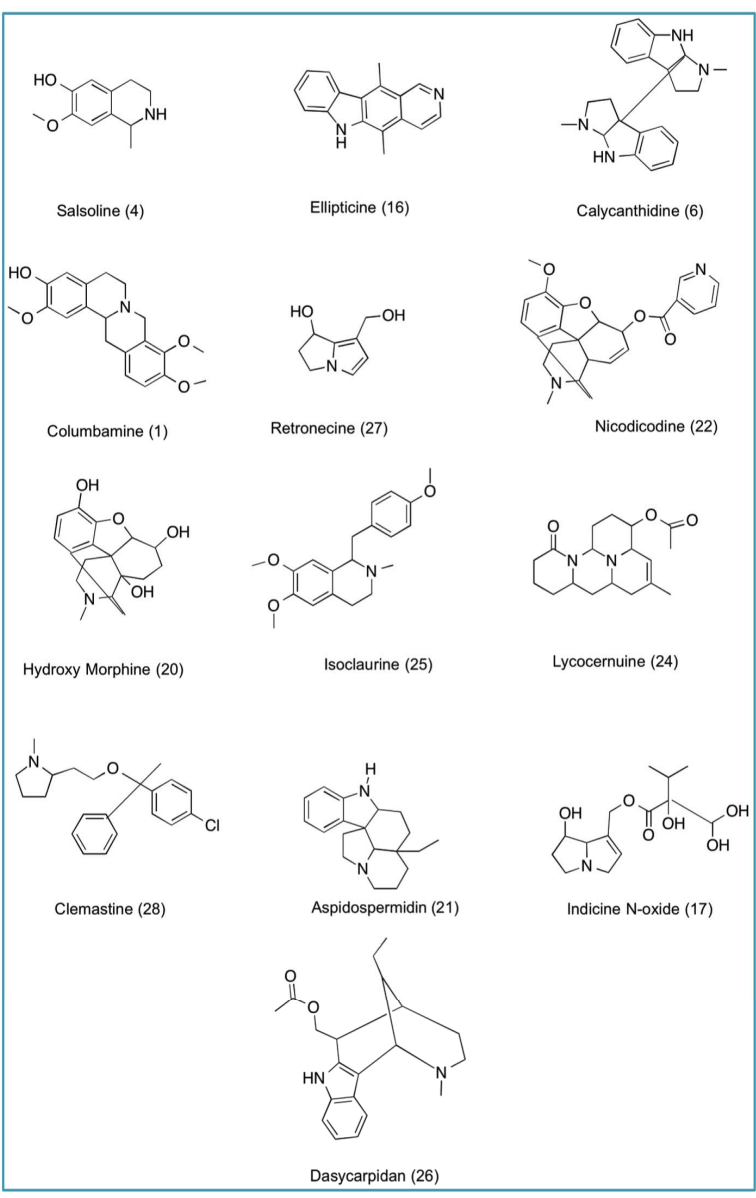

(b)

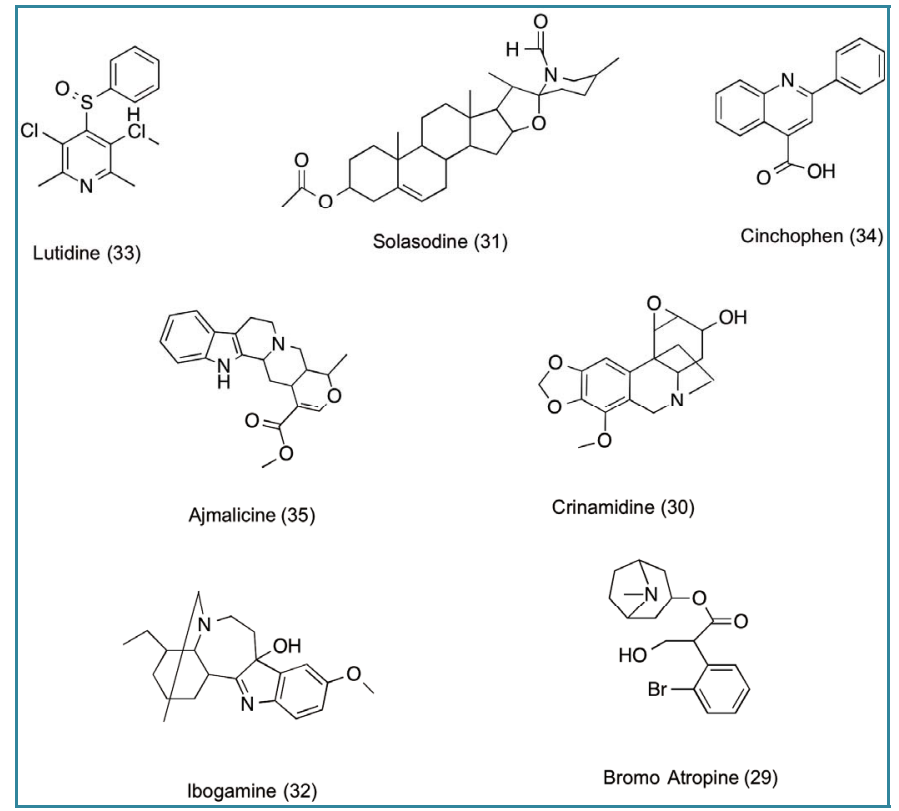

(c)

Figure 2. (a) Alkaloids identified in F. benjamina leaves (1) extracts; (b) Alkaloids identified in F. benjamina leaves (2) extracts; (c) Alkaloids identified in $F$. benjamina barks extracts. 
(0.36\%), lycocernuine (24) $(0.22 \%)$, isoclaurine (25) (0.03\%), dasycarpidan (26) $(0.15 \%)$, retronecine (27) $(0.06 \%)$, clemastine (28) $(0.09 \%)$. In bark extract the more abundant alkaloids are anabasine (8) $(24.85 \%)$, p-bromo atropine (29) (28.09\%), columbamine (1) (17.13\%), laudanosoline (2) (14.79\%); alkaloids with abundance class from $5 \%$ to $10 \%$ are not present; while under $5 \%$ relative abundance class we found crinamidine (30) (4.22\%), oscurinervinediol (14) (2.81\%), matridine (18) (2.24\%), solasodine (31) (1.36\%), nicodicodine (22) (1.42\%), ibogamine (32) (1.10\%), lutidine (33) (0.73\%), cinchophen (34) $(0.57 \%)$, ajamalicine (35) $(0.21 \%)$, dasycarpidol (36) $(0.42 \%)$. The comparison between the areas of alkaloids in leaves and barks exhibit that total areas of leaves alkaloids are 4 times more abundant then total alkaloid areas in barks extract. In Figure 3 a comparison of principal alkaloids identified in leaves and barks extracts are reported: compounds 1, 2, and 14 are present in both extracts in different concentrations. Compounds 3, 4, 5 are present only in leaves extracts, while alkaloid 29 is present only in barks extracts. For each alkaloid, the spectrum of single chemical species characterized is compared with items registered in the NIST library. The identification was performed according to evaluation of similarity percentage above the $80 \%$.

More abundant molecules are alkaloids from isoquinoline class as $2(17.17 \%)$ in leaves and (14.79\%) in barks, $\mathbf{1}(31.07 \%)$ in leaves and (17.13\%) in barks, $3(9.63 \%)$ and $\mathbf{4}(8.61 \%)$. As reported in literature [30] isoquinoline alkaloids exhibit strong pharmacologic activity: berberine, sanguinarine, magnoflorine, tetrandine and aromoline alkaloids from this class showed lipid-reducing activity in Caenorabditis elegans. Compound $\mathbf{2}$ is an alkaloid characterized in species like Sinomenii caulis [31]. Authors showed that plants of Sinomenii with larger diameters has proportionately more bioactive components, like 2 , and is therefore employed for medicinal use. A study of benzylisoquinoline alkaloids showed that some of them ( 2 and papaverine derivatives) were particularly effective as antioxidant agents, thanks to the presence of free hydroxyl group that are a feature relevant for inhibition of lipid peroxidation and nitrotetrazolium blue reduction. Isoquinoline alkaloids from Berberis spp., like compound 1, isolated from roots showed a significant anti-inflammatory, antinociceptive and antipyretic effects. Briefly, $\mathbf{1}$ showed anti-inflammatory activity in in vivo models; this alkaloid exhibit a mechanism of action similar to others anti-inflammatory agents, causing the inhibition of prostaglandins biosynthesis. Furthermore, $\mathbf{1}$, by blocking biosynthesis of prostaglandins, plays an important role as antipyretic agent. As well know a trigger agent of the fever, pyrogen, release prostaglandins that acts on the hypothalamus and generates a systemic response in the rest of the body, causing heat-creating effects. Compound $\mathbf{1}$, by blocking prostaglandins formation, reduces the higher temperature and symptoms of fever [32]. A previous paper [32] test 1 and others isoquinolines alkaloids for a putative anti-nociceptive activity from Berberis spp. As well know the prostaglandins contributes also to pain hypersensitivity, exciting nociceptive neurons through direct activation of nociceptor-specific ion channel transient receptor potential A1 (TRPA1). Considering that, was hypothesized anti-nociceptive activity of this molecule $\mathbf{1}$, thanks their ability to block the synthesis of prostaglandins. The preliminary analysis in models shows that all alkaloids tested exhibit inhibition of the pain but in a not significant ways [33]. In a recent study [34], 1 was applied for the treatment of osteosarcoma, a malignant bone tumor that affects children and adolescents. The neovascularization play an important role in the tumor growth and metastasis, by a direct

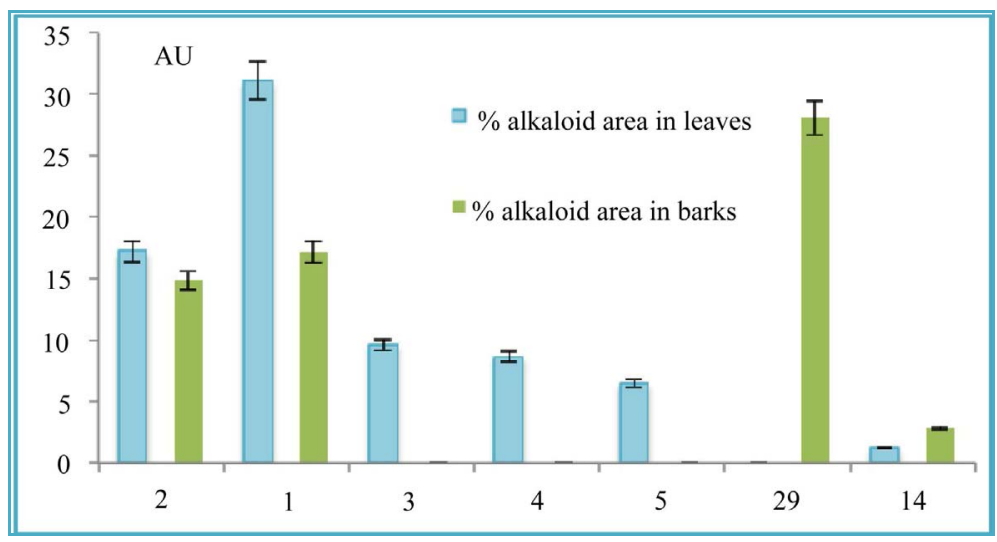

Figure 3. A comparison from principal alkaloid identified in F. benjamina leaves and barks. Compounds are identified with their relative numbers. SD $<$ $5 \%$. 
formation of tumor blood vessels through vasculogenic mimicry. Against the proliferation and neovascularization of tested U2OS osteosarcoma cell line, 1 act on the cell cycle, by inhibiting the expression of CDK6 gene in G1 phase (cell growth phase), and by increasing the expression of p53 gene involved in apoptosis of tumor cells, compound 1 exerts anti-proliferative and anti-vasculogenic effects on metastatic osteosarcoma cells with very low cytotoxicity, becoming a new candidate for the treatment of osteosarcoma therapy [34], as well as this molecule can be use for the treatment of other neoplastic diseases. Another significant pharmacological compound is $\mathbf{4}$ that derives from catecholamines like dopamine that condense with aldehydes forming tetrahydropapaveroline, salsolinol and the molecule 4 [35]. The compound 4 work as $\beta_{1}$ receptor agonist on the cardiac muscle cells, causing an increase in the heart contractility and showing to be more potent then adrenaline because probably 4 compete with adrenaline to bind $\beta$ receptor. Its efficacy derives from a methyl group that is significantly related to the pharmacological activity of the alkaloid in the ventricular myocardium [35]. According to a recent study [36], 4 also show antitumoral activity correlated to immonium rings present in its structure. According to the literature [37], compound 3, from Annona squamosa twigs show a significant anti-ulcer activity, acting like omeprazole proton pump inhibitor, blocking $\mathrm{H}^{+} / \mathrm{K}^{+}$ATPase, involved in acid secretion and by suppressing the release of gastrin hormone, that modulate acid secretion by parietal cells. In conclusion this compound may serve as starting point for the design of novel semi-synthetic and synthetic compounds as anti-ulcer agents [37].

Screening of alkaloids in $F$. benjamina show other interesting class-derivative alkaloids for their pharmaceutical activity: quinolizidine and tropane classes: $19(0.65 \%)$ and $29(28 \%)$. Literature [38] shows that compound 19 extracted from Corydalis dubia proved to be very effective in blood, bile, and liver infections related to malaria disease. Particularly, show a very significant action against the multidrug resistant strains of Plasmodium falciparum $\mathrm{K} 1 \mathrm{CB} 1$ [38] probably with a very similar mechanism to chloroquine antimalarian quinoline drug.

The tropane class alkaloids generally found in Solanaceae family were significantly evidenced in F. benjaminabarks as compound 29. The mechanism of action of tropane alkaloids like $\mathbf{2 9}$ is their competitive antagonism against muscarinic acetylcholine receptors, preventing the binding of acetylcholine [39]. According to the specificity and selectivity of muscarinergic acetylcholine receptors in different organs, they modulates the functions of smooth muscles and exocrine gland cells, as well as the heart rate, respiration and functions in the central nervous system [39].

GC-MS analysis also exhibits presence of minor alkaloids (with relative abundance $<5 \%$ ). These include: compound 8 (from pyridine class), present at $2.2 \%$ in leaves and $2.85 \%$ in barks. The alkaloid 8 is extracted mostly from tobacco tree. Its use is common in agriculture field as insecticide, but its utility is limited because of its toxicity in humans. Recent study [40] proved that 8 concentrations in urine can be used to validate abstinence or measure the extent of tobacco use in persons in nicotine replacement therapy because $\mathbf{8}$ is decomposed to a much greater extent in burning tobacco then nicotine; compound 7 indole class (3.04\%), from Alstonia scholaris is used in the treatment of chronic respiratory disease, like asthma and obstructive pulmonary disease, by activating $\beta_{2}$ receptors and inhibiting NF $\mathrm{KB}$ [41], known to be one of the promoter of inflammation in both disease [42]. The alkaloid $4(6.42 \%)$ is able to reduce the heart rate and blood pressure in normotensive rats [43]. This effect was confirmed by $\mathbf{4}$ from different species of the genus Ocotea that proved the vasorelaxation induced by this alkaloid through the inhibition of L-type $\mathrm{Ca}^{2+}$ channels. So, $\mathbf{4}$ may have interesting potential as a chemical model for a putative development of new drugs with cardiovascular-protective properties [44]. Previous paper [45] tested $\mathbf{4}$ against hepatitis B, a disease that causes acute and chronic infections of the liver and is responsible for 1.2 million deaths annually. Scientific data showed that this alkaloid from Hypserpanitida act against HBV surface and $\mathrm{HBVe}(\mathrm{HBeAg})$ antigens; indolizidine alkaloid $\mathbf{3 0}$ from Amaryllidaceae show an important activity against acethylcholinesterase enzyme becoming a possible alternative for galanthamine in the treatment of Alzheimer's disease [46]; indole compounds like 6 were synthetized by the precursor hodgskinsine, from Psychotria spp. (Rubiaceae) were evaluated in vitro and in vivo along with the synthetic intermediates for a possible antinociceptive activity. Neuropathic pain following injury to the nervous system responds poorly to opiates at doses that do not cause serious adverse effects. Thus, alternative management strategies, with the use of these alkaloids able to binding with higher affinity to opioids receptors, were need to be considered for dealing with situations where pain is unresponsive to currently available medication [47].

\section{Conclusion}

Through our work, we identified the presence of numerous and different alkaloids in Ficus spp. that previous papers reported have potent biological activities (anticancer, antimicrobial, anti-oxidant, anti-muscarinic activi- 
ties etc.). Although the alkaloid are widely used in human health and nutrition, and mainly obtained by extraction from plant, the yield from $F$. benjamina extraction is low because most of these metabolites accumulate at not high levels in these plant tissues. However $F$. benjamina extracts evidenced a higher variety of alkaloids that can act as potent phytocomplex and with higher antioxidant power. Even though, $F$. benjamina species deserve more deep investigations finalized to develops its pharmaceutical properties using plant metabolic engineering to increase the amounts of secondary metabolites. Moreover, cell culture approach provides continuous, reliable and renewable source of valuable plant pharmaceuticals and might be used for the large scale culture of plants.

\section{Notes}

The authors declare no competing financial interest.

\section{References}

[1] Acharya, D. and Shrivastava, A. (2008) Indigenous Herbal Medicine: Tribal Formulations and Traditional Herbal Practices. 1st Edition, Avishkar Publishers, Jaipur.

[2] Aniszewski, T. (2007) Alkaloids - Secrets of Life Alkaloids Chemistry, Biological Significance Application and Ecological Role. 1st Edition, Elsevier, Amsterdam.

[3] Podsędek, A. (2007) Natural Antioxidants and Antioxidant Capacity of Brassica Vegetables: A Review. Food Science and Technology, 40, 1-11.

[4] Maestri, D.M., Nepote, V., Lamarque, A.L. and Zygadlo, J.A. (2006) Natural Products as Antioxidants. In: Trivandrum, I.F., Ed., Phytochemistry: Advances in Research, Research Signpost, Córdoba, 105-135.

[5] Dang, S., Yan, H., Yamamoto, S., Wang, X. and Zeng, L. (2004) Poor Nutritional Status of Younger Tibetan Children Living at High Altitudes. European Journal of Clinical Nutrition, 58, 938-946.

http://dx.doi.org/10.1038/sj.ejen.1601915

[6] Chaurasia, O.P., Ballabh, B. and Singh, B. (2003) Himalayan Rose Root, Rhodiola spp. Potential Health Drink and Drug Plant. Natural Product Radiance, 2, 71-92.

[7] Ali, R., Jaimini, A., Nishad, D.K., Mittal, G., Chaurasia, O.P., Kumar, R., Bhatnagar, A. and Singh, S.B. (2012) Acute and Sub Acute Toxicity and Efficacy Studies of Hippophaerhamnoides Based Herbal Antioxidant Supplement. Indian Journal of Pharmacology, 44, 504-508. http://dx.doi.org/10.4103/0253-7613.99329

[8] Hegedus, A., Engel, R., Abrankó, L., Balogh, E., Blázovics, A., Hermán, R., Halász, J., Ercisli, S., Pedryc, A. and Stefanovits-Bányai, É. (2010) Antioxidant and Antiradical Capacities in Apricot (Prunus armeniaca L.) Fruits: Variations from Genotypes, Years, and Analytical Methods. Journal of Food Science, 75, 722-730. http://dx.doi.org/10.1111/j.1750-3841.2010.01826.x

[9] Yadav, A., Stobdan, T., Dwivedi, S.K., Korekar, G., Targais, K. and Srivastava, R.B. (2011) Apricot (Prunus armeniaca L.) for Livelihood Security in Cold Deserts. In: Srivastava, R.B. and Selvamurthy, W., Eds., Innovations in Agro Animal Technologies, Satish Serial Publishing House, Delhi, 87-97.

[10] Chaurasia, O.P., Hota, S.K., Kumar, R., Tayade, A.B. and Srivastava, R.B. (2011) Trans-Himalayan Medicinal Plants and Herbal Nutraceutical Products. In: Srivastava, R.B. and Selvamurthy, W., Eds., Innovations in Agro Animal Technologies, Satish Serial Publishing House, Delhi, 113-129.

[11] Kala, C.P. (2006) Medicinal Plants of the High Altitude Cold Desert in India: Diversity, Distribution and Traditional Uses. International Journal of Biodiversity Science \& Management, 2, 43-56. http://dx.doi.org/10.1080/17451590609618098

[12] Chaurasia, O.P., Ahmed, Z. and Ballabh, B. (2007) Ethnobotany and Plants of Trans-Himalaya. Satish Serial Publishing House, Delhi.

[13] Liyana-Pathiranan, C.M. and Shahidi, F. (2005) Antioxidant Activity of Commercial Soft and Hard Wheat (Triticum aestivum L.) as Affected by Gastric pH Conditions. Journal of Agricultural and Food Chemistry, 53, 2433-2440. http://dx.doi.org/10.1021/jf049320i

[14] Lansky, E.P., Paavilainen, H.M., Pawlus, A.D. and Newman, R.A. (2008) Ficus spp. (fig): Ethnobotany and Potential as Anticancer and Anti-Inflammatory Agents. Journal of Ethnopharmacology, 119, 195-213. http://dx.doi.org/10.1016/j.jep.2008.06.025

[15] Baumgartner, B., Erdelmeier, C.A.J., Wright, A.D., Rali, T. and Sticher, O. (1990) An Antimicrobial Alkaloid from Ficusseptica. Phytochemistry, 29, 3227-3330. http://dx.doi.org/10.1016/0031-9422(90)80209-Y

[16] Mohammad, H., Sutradhar, M.A. and Ranjrr, K. (1991) Chemical Constituents of Ficus glomerata Roxb. Journal of 
the Bangladesh Chemical Society, 4, 247-250.

[17] Khan, I.A., Rali, T. and Sticher, O. (1993) Alkaloids from Ficus pachyrhachis. Planta Medica, 59, 286. http://dx.doi.org/10.1055/s-2006-959677

[18] Ilyas, M. and Ilyas, N. (1990) Flavonoids from the Leaves of Ficus capensis. Ghana Journal of Chemistry, 1, $176-178$.

[19] Frith, H.J., Rome, F.H.J. and Wolfe, T.O. (1976) Food of Fruit-Pigeons in New Guinea. Emu, 76, 49-58. http://dx.doi.org/10.1071/MU9760049

[20] Almahyl, H.A., Rahmani, M., Sukarp, M.A. and Ali, A.M. (2003) Investigation on the Chemical Constituents of the Leaves of Ficus elastica Roxb. and Their Antimicrobial Activity. Pertanika Journal of Science \& Technology, 11, 57-63.

[21] Parajuli, S.P. (2000) Ethnobotanical Studies of at Khandbarimuncipilty of Sankhuwasabha. BankoJanakari, 10, 29-34.

[22] Sirisha, N., Sreenivasulu, M., Sangeeta, K. and Chetty, C.M. (2010) Antioxidant Properties of Ficus Species: A Review. International Journal of PharmTech Research, 4, 2174-2182.

[23] Kanaujia, V.K., Rirchhaiya, H.K., Kailasiya, S.D., Verma, M., Yadav, R.D. and Shivhare, D. (2011) Evaluation of Hepatoprotective Activity on the Leaves of Ficus benjamina Linn. Journal of Natural Product \& Plant Resources, 1, 59-69.

[24] Dai, J., Shen, D., Yoshida, W.Y., Parrish, S.M. and Williams, P.G. (2012) Isoflavonoids from Ficus benjamina and Their Inhibitory Activity on BACE1. Planta Medica, 78, 1357-1362. http://dx.doi.org/10.1055/s-0032-1315001

[25] Angelo, G., Lorena, C., Marta, G. and Antonella, C. (2014) Biochemical Composition and Antioxidant Properties of Lavandula angustifolia Miller Essential Oil Are Shielded by Propolis against UV Radiations. Photochemistry and Photobiology, 90, 702-708. http://dx.doi.org/10.1111/php.12229

[26] Shamsa, F., Monsef, H., Ghamooshi, R. and Verdian-rizi, M. (2008) Spectrophotometric Determination of Total Alkaloids in Some Iranian Medicinal Plant. Thai Journal of Pharmaceutical Sciences, 32, 17-20.

[27] Esmaeili, A.H., Moghaddam, A.H. and Chaichi, M.J. (2013) Identification, Determination, and Study of Antioxidative Activities of Hesperetin and Gallic Acid in Hydro-Alcoholic Extract from Flowers of Eriobotrya japonica L. Avicenna Journal of Phytomedicine, 4, 260-266.

[28] Wong, S.K., Lim, Y.Y., Abdullah, N.R. and Nordin, F.J. (2011) Antiproliferative and Phytochemical Analyses of Leaf Extracts of Ten Apocynaceae Species. Pharmacognosy Research, 3, 100-106. http://dx.doi.org/10.4103/0974-8490.81957

[29] Piana, M., Boligon, A.A., Brum, T.F., Zadra, M., Belke, B.V., Froeder, A.L., Frohlich, J.K., Nunes, L.T., Pappis, L., Boligon, A.A. and Athayde, M.L. (2014) Phytochemical Analysis and Antioxidant Capacity of Tabernaemontana catharinensis A. D.C. Fruits and Branches. Anais da Academia Brasileira de Ciências, Epub Ahead of Print.

[30] Chow, Y. and Sato, F. (2013) Screening of Isoquinoline Alkaloids for Potent Lipid Metabolism Modulation with Caenorhabditis elagans. Bioscience, Biotechnology, and Biochemistry, 77, 2405-2412. http://dx.doi.org/10.1271/bbb.130523

[31] Yi, L., Liang, Z.T., Peng, Y., Yao, X., Chen, H.B. and Zhao, Z.Z. (2012) Tissue-Specific Metabolite Profiling of Alkaloids in Sinomenii Caulis Using Laser Microdissection and Liquid Chromatography-Quadruple/Time of Flight-Mass Spectrometry. Journal of Chromatography A, 1248, 93-103. http://dx.doi.org/10.1016/j.chroma.2012.05.058

[32] Kupeli, E., Koçar, M., Yesilada, E. and Baser, K.H.C. (2002) A Comparative Study on the Anti-Inflammatory, Antinociceptive and Antipyretic Effects of Isoquinoline Alkaloids from the Roots of Turkish Berberis Species. Life Sciences, 72, 645-657. http://dx.doi.org/10.1016/S0024-3205(02)02200-2

[33] Taylor-Clarke, T.E., Undem, B.J., Macglashan, D.W., Ghatta, S., Carr, M.J. and McAlexander, M.A. (2007) Prostaglandin-Induced Activation of Nociceptive Neurons via Direct Interaction with Transient Receptor Potential A1 (TRPA1). Molecular Pharmacology, 73, 274-281. http://dx.doi.org/10.1124/mol.107.040832

[34] Bao, M.M., Cao, Z.F., Yu, D., Fu, S.L., Zhang, G.C., Yang, P., Pan, Y.Y., Yang, B., Han, H.Y. and Zhou, Q.S. (2012) Columbamine Suppresses the Proliferation and Neovascularization of Metastatic Osteosarcoma U2OS Cells with Low Cytotoxicity. Toxicology Letters, 215, 174-180. http://dx.doi.org/10.1016/j.toxlet.2012.10.015

[35] Chavez, L., Ponce, M.T., Bravo, G. and Pastelin, G. (1989) Pharmacological Study of Dopamine Catabolites on the Contractility of Isolated Guinea Pig Myocardium. Archivos del Instituto de Cardiología de México, 59, $367-373$.

[36] Kuznetsova, N.N., Abdullaeva, L.K. and Sadikov, A.A. (2005) Comparative Action of Salsoline, Salsolidine and Related Compounds on KML Tissue Culture and Animal Tumor Strains. Chemistry of Natural Compounds, 41, 234-235. http://dx.doi.org/10.1007/s10600-005-0121-z

[37] Yadav, D.K., Singh, N., Dev, K., Sharma, R., Sahai, M., Palit, G. and Maurya, R. (2010) Anti-Ulcer Constituents of Annona squamosal Twigs. Fitoterapia, 82, 666-675. http://dx.doi.org/10.1016/j.fitote.2011.02.005 
[38] Wangchuck, P., Keller, P.A., Pyne, S.G., Wyllis, A.C. and Kamchonwongpaisan, S. (2012) Antimalarial Alkaloids from a Bhutanese Traditional Medicinal Plant Corydalis dubia. Journal of Ethnopharmacology, 143, 310-313.

[39] Alexander, J., Benford, D., Cockburn, A., Cravedi, J.P., Dogliotti, E., Di Domenico, A., Férnandez-Cruz, M., Fürst, F., Fink-Gremmels, J., Galli, C.L., Grandjean, P., Gzyl, J., Heinemeyer, G., Johansson, N., Mutti, A., Schlatter, J., Van Leeuwen, R., Van Peteghem, C. and Verger, P. (2008) Tropane Alkaloids (from Datura sp.) as Undesirable Substances in Animal Feed. EFSA Journal, 691, 1-55.

[40] Jacob III, P., Hatsukami, D., Severson, H., Hall, S., Yu, L. and Benowitz, N. (2002) Anabasine and Anatabine as Biomarkers for Tobacco Use during Nicotine Replacement Therapy. Cancer Epidemiology, Biomarkers \& Prevention, 11, 1668-1673.

[41] Hou, Y.Y., Cao, X.L., Wang, L.Q., Cheng, B.F., Dong, L.Y., Luo, X.D., Bai, G. and Gao, W.Y. (2012) Microfractionation Bioactivity-Based Ultra Performance Liquid Chromatography/Quadrupole Time-of-Flight Mass Spectrometry for the Identification of Nuclear Factor- $\kappa$ B Inhibitors and $\beta 2$ Adrenergic Receptor Agonists in an Alkaloidal Extract of the Folk Herb Alstonia scholaris. Journal of Chromatography, 908, 98-104.

[42] Edwards, M.R., Bartlett, N.W., Clarke, D., Birrell, M., Belvisi, M. and Johnston, S.L. (2009) Targeting the NF- $\kappa$ B Pathway in Asthma and Chronic Obstructive Pulmonary Disease. Pharmacology \& Therapeutics, 121, 1-13. http://dx.doi.org/10.1016/j.pharmthera.2008.09.003

[43] Dias, K.L., Da Silva Dias, C., Barbosa-Filho, J.M., Almeida, R.N., De Azevedo Correia, N. and Medeiros, I.A. (2004) Cardiovascular Effects Induced by Reticuline in Normotensive Rats. Planta Medica, 70, 328-333.

[44] Medeiros, M.A.A., Nunes, X.P., Barbosa-Filho, J.M., Lemos, V.S., Pinho, J.F., Roman-Campos, D., De Medeiros, I.A., Araújo, D.A.M. and Cruz, J.S. (2008) (S)-Reticuline Induces Vasorelxation through the Blockage of L-Type Ca ${ }^{2+}$ Channels. Naunyn-Schmiedeberg's Archives of Pharmacology, 379, 115-125. http://dx.doi.org/10.1007/s00210-008-0352-1

[45] Cheng, P., Ma, Y., Yao, S., Zhang, Q., Wang, E., Yan, M., Zhang, X., Zhang, F. and Chen, J. (2007) Two New Alkaloids and Active Anti-Hepatitis B Virus Constituents from Hypserpa nitida. Bioorganic \& Medicinal Chemistry Letters, 17, 5316-5320. http://dx.doi.org/10.1016/j.bmcl.2007.08.027

[46] Elgorashi, E., Stafford, G.I. and Van Staden, J. (2004) Acetylcholinesterase Enzyme Inhibitory Effects of Amaryllidaceae Alkaloids. Planta Medica, 70, 260-262. http://dx.doi.org/10.1055/s-2004-818919

[47] Verotta, L., Orsini, F., Sbacchi, M., Scheildler, M.A., Amador, T.A. and Elisabetsky, E. (2002) Synthesis and Antinociceptive Activity of Chimonanthines and Pyrrolidinoindoline-Type Alkaloids. Bioorganic \& Medicinal Chemistry, 10, 2133-2142. http://dx.doi.org/10.1016/S0968-0896(02)00078-0 
Scientific Research Publishing (SCIRP) is one of the largest Open Access journal publishers. It is currently publishing more than 200 open access, online, peer-reviewed journals covering a wide range of academic disciplines. SCIRP serves the worldwide academic communities and contributes to the progress and application of science with its publication.

Other selected journals from SCIRP are listed as below. Submit your manuscript to us via either submit@scirp.org or Online Submission Portal.
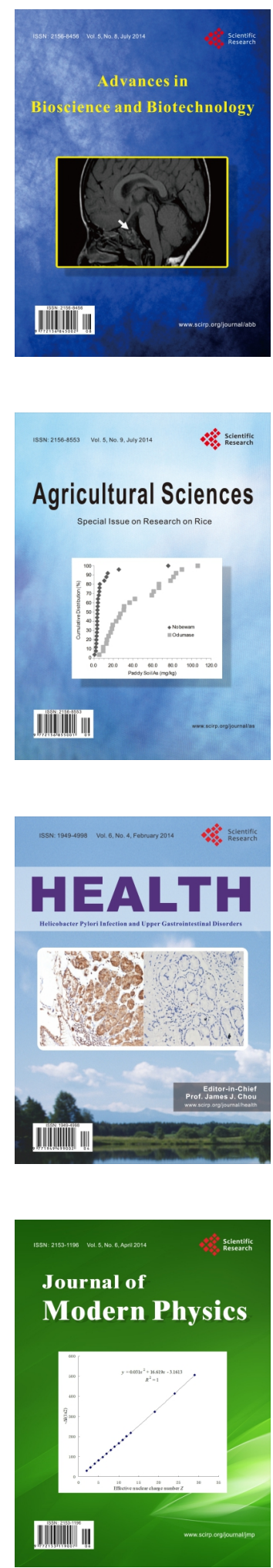
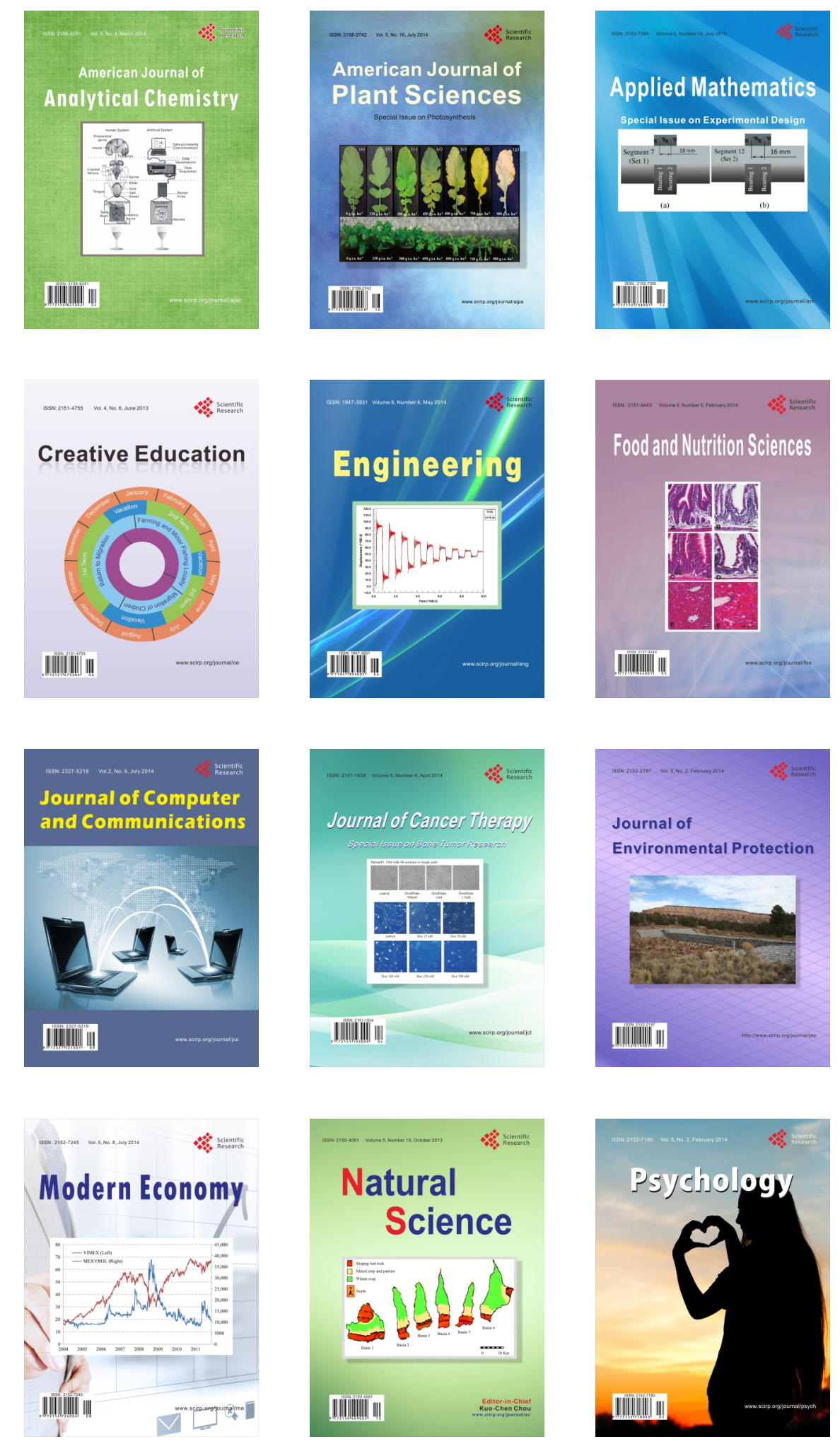